Litinfinite Journal

ISSN: 2582-0400 [Online]

CODEN: LITIBR

Vol-1, Issue-1 ( $2^{\text {nd }}$ July, 2019)

Page No: $15-22$

DOI: 10.47365/litinfinite.1.1.2019.15-22

Section: Article

\title{
Rumi and Iqbal's Concept of Divine Love, a Brief Analysis
}

\author{
Dr. Ateequllah Dar \\ M.Phil and Ph.D in Philosophy \\ Lecturer - Department of Philosophy \\ Women's Collage, Baramulla, Kashmir, India. \\ President J\&K Philosophy Association \\ Mail Id: dar.ateequllah14@gmail.com
}

\begin{abstract}
This paper is written on the two multi-genius thinkers who were globally acknowledged to be the greatest poet philosphers/ and mystic par-excellence of the Islamic history. Rumi (Peer-eRumi)belongs to $13^{\text {th }}$ century and Muradee-Hindi (Iqbal) belongs to the $19^{\text {th }}$ century. Both have a close affinity on many facets and were imbibed with Islamic cannons, beliefs, norms, values and injuctions. Both were adequates of love, peace and oneness of mankind. In all creations, divine love is the crux in their philosophical systems.

This paper is an attempt to highlight some similar glimpses of love as it is commonly misunderstood as solely a romantic relation between two individuals or two objects. Notwithstanding hardly anyone knows what the Divine Love is. Mere love to physical objects is an ephemeral, a lust and intense attachment of worldly pleasures which is a superficial understanding of true love. Divine Love is a central theme in their philosophy, a sublime, holy and remedy for all ailments of man's weakness. It is an ever-going activity without ending process. It is neither lust nor phantasy. It transcendences all worldly bondage and thus makes a man ture human according to Rumi and Iqbal.
\end{abstract}

Key-Words: Tranquillity, Transcendence, shilly-shalies,dilly-dallies

\section{God is in search of a man who is really a man}

\section{Shamas-i-Tabrez}

\section{Rumi's Imapct on Iqbal}

One is said to be the guide if he is the epitome of love, compasion, embodiment of knowledge and incarnation of the action, all these attributes where found in Rumi by Iqbal. He expounds that:

Rumi turned the soil into an elixer. He has in me,

Who is as valuable as dust, many; many manifestations. It was as if a particle from the desert soil set on a journey To obtain the light of the sun. I am a wave. I settled in his Sea in order to obtain a bright pearl. Rumi, who is not seperate From God, has manifested himself to me. It was that Rumi who

Composed a Quran in the persian language. He told me; 
Litinfinite Journal

ISSN: 2582-0400 [Online]

CODEN: LITIBR

Vol-1, Issue-1 (2 $\left.{ }^{\text {nd }} J u l y, 2019\right)$

Page No: $15-22$

DOI: 10.47365/litinfinite.1.1.2019.15-22

Section: Article

O bewildered lover! Take a sip from the pure wine of the divine Love.....

Asrar-e Khudi, Translated by A.R Nicolson

Iqbal again says,

The west hath cast a spell on yours heart and mind

In Rumi's burning flame a cure for yourself find...

Bale. Jabriel

While entering the cosmos of Iqbal, we see both within one another that is the real nexus between the guide and desciple. Iqbal treated Rumi as his friend, guide and philosopher. He was impressed by Rumi so much so that mentioned him in all his creations. Though there is a grave difference between the two. The answer is provided by Mathnavi-the greatest treasure in persian and world literature. Rumi himself confess the claim that a student of Mathnavi may not become a saint but will certainly escape from the influence of Satan. It was out of Mathnavi and its mysterious guidence that raises Iqbal to the skies of Marifath (Knowledge or Gnosis) and Tahheed (belief in the oneness of God).

\section{Rumi in the eyes of Wits}

In Hegal's conviction, Rumi is one of the greatest poets and most important thinkers in the world history. In the high rank and profile, A.R Nicholson, the eminent British orientlist praised him as "the greatest mystical poet of any age. Jami one of the immortals of Persian literature, said in his remarkable remark, "He is not a prophet, but he has written a Holy book" referring to his Mathnavi-having acryptic voice, the voice which has also been called Quran.

\section{Masnaviou Moulavaiou, Manaovi}

\section{Hast Quran Dar Zubani Pahlavi}

Rumi in the standpoint of Halman, may well be the only major philosopher in history to express and formulate an entire system of thought in verse as he speaks of the sacred in nature and in humanity with a great confidence and assurance.

\section{Idea of Love}

World is a world of love. It is eternal and indomitable, indescribable, beyond space and everything above measurement, form or shape. It is transcendence of the Divine-beyond shilly-shalies and dilly-dallies. Love is oneness of mutual souls. As such the whole cosmic phenomenon is when there it is. "To love God is to know God."1 It is an understandable nub to those who fall in that love.

\footnotetext{
${ }^{1}$ Fadiman James and Frager Robert, Essential Suffism, Second Published Books, 2009, P. No 113
} 
Love is fair in Divinity. It is a real worship, free from anxiety, fear, restlessness and all calculations. It guarantees Holy presence. For it is eternal gnome as God Himself. What remains is the reason, a baffling facet of man. Unless one is unconscious of it can't take flight to the Absolute. So count no one great till he is dead. God is love and he that dwelled in love dwelled in God. Who proves to be a lover but is a matter of present. It is neither acquired from Cambridge nor from oxford, neither from Rome nor from Greek, neither from masjid nor from temple. True lover is the one who goes deep into the self to get the self actualization, to get beloved, the Creator of the Created, the Cherisher of the cherishing, the Maker of the made. Now the nabbing query is who the true lovers are, those who live in ecstasy, who die in ecstasy, who see in ecstasy, and who are blind in ecstasy.

Most of the people misunderstand the concept of love and comprehend it is an emotion between two individuals or two objects. It is true but something higher than that is a greater truth. It is an emotion recollected in tranquility. It is a fusion which the reason fails to know. It is a synthesis which results in creation or production. It has a force of melting everything into itself. This whole cosmology is integerated on the principle of synthesis which is love. Any kind of grain finding a suitable soil turns into a plant where as the same grain put in the bed of sand either rots or decomposes whithout turning into a plant. It is because the principle of synthesis is not well adjusted. In the same way when mind turns into the secrets of self with full force of attention, the result is sainthood which is the highest form of love. This bent of mind in Dr Iqbal is granted by Molana Rumi in abundance and likewise Molana Rumi found this dazzling illumination from Shams Tabrizi, who was his spiritual guide. It is his mysterious guidence that raised Jalal-Uddin Rumi to the skies of Tareqaat, Marifat, and Tawheet. Dr Iqbal accepts wholeheartedly:

\section{Molvi Hargiz Na Shuud Molaeea Rumm \\ Ta Gulaama Shamas Tabrezi Na Shud}

Rumi has been the shinning son in Islamic Mysticism. It is he who proved to be the true source of inspiration for Iqbal's Mystic faith. Iqbal himself claims of Rumi being his true spiritual guide and Guider-by-hand:

Pir-e-Rumi Khaak Ra Aksir Karadh, Az Ghubaram Jalveh Ha Tameer Kardh

Master Rumi transformed my dust into Alchemy

And changed my body into an effulgent one

The base stone of love in the sphere of Rumis ecstasy is a form of Arabic dictum:

\section{Maan Arfa Nafsahu, Fakaadh Arfa Rabahu \\ Who realises himself, realises God}

After passing the obligation, the pangs of love leaving behind matter of vicillation, reach to the zenith where eternal felicity and peace is gotten. Rumi as a true lover and guide opines to get lost within leaving the riff-raff reason

Dafteer-e-sufi savada harf neesteJuz dil-e aspeed ham choo barf neeste 
Litinfinite Journal

ISSN: 2582-0400 [Online]

CODEN: LITIBR

Vol-1, Issue-1 (2 ${ }^{\text {nd }}$ July, 2019)

Page No: $15-22$

DOI: 10.47365/litinfinite.1.1.2019.15-22

Section: Article

Zade Danishmand aseera kalmZade sufi cheest anwari kidam

Love thus is a mystery, powerful weapon, beyond the jurisdiction of empericalworld. In general, rationalistically, God may be reason, but for the mystic, He is love. Intellect and reason lack the gift of transcendence whereas a mystic consumes himself for the power of soul. What eyes fail to see, a mystic can float on; comprehend till he reaches a stage of unison with God-his creator. It is the human emancipation. It takes its course from where the reason being a fragmentary human generalization is lost. To Rumi, this very reaon is ever deluding and confusing weather to be or not be. Love is ever silent and never roaring or chaotic. Here Iqbal comes to be the espouser of the same analogy. To secrets of self, love is described as the relentless longing of assimilation and absorption. In Iqbalinism many appellations are given to love, the ever debated and discussed term like shoaq, Masti, Sooz, Khudi, Arzoo. Iqbal putout the subject matter in the below mentioned verses:

\section{Akal Wa Dil Wa Nigha Ka Murshad Awleen Hain Ishq \\ Ishq Na Hoo Too Shariah Wa, Din Buth Quada Tasavrath \\ Jaware Zindage Hain Ishq,Jaware Ishq Hian Khudi \\ Aw Ki Hain Yeh Tayki Taaz Pardagee Niyam Abhee}

According to Rumi and Iqbal, the main obstruction in the path of Divine love, is arrogance and conceit, ostentation, jealousy, hate, suspension, anger, love of power, name and fame, etc. Iqbal further says:

Kafir kee Yhe Pachaan Hain ki Afaq Ma Gum Hain

Momin Kee Yhe Pachaan Hain Ki Gum Usma Hain Afaq (Iqbal-Zare-Kaleem)

Thus a true human is one who has Divine longing. Like a compass one has to rotate round his own self, instead of raising fingures on others, one has to introspect oneself (Tazkiya), as it helps to attain spiritual growth by looking deep into inner-self, examining and evaluating all past actions and thoughts, studying man's fears and desires. In the absence of this truth is veiled and hidden panache is died and destroyed. Hence, it is self awareness that rules and regulates the continumm of true give and take proecss, the base stone of creation. William Shakespeare in his 'Venus and Adonis', expounds:

Love comforteth like sunshine after rain,

But lus's effect is tempest after sun:

Love's gentle spring doth always fresh remain;

Lust's winter comes ere summer half be done;

Love surfeits not, lust like a glutton dies;

Love is all truth, lust full of forged lies. ${ }^{2}$

William Words Worth espouses in his poetry, "Tintern Abbey", love as if someone indulges or falls in love with some object other than the beloved then it is impure, an act of absurdity or foolishness:

\footnotetext{
${ }^{2}$ Puri Lekh Raj, Mysticism the spiritual path, P. No 495
} 
Litinfinite Journal

ISSN: 2582-0400 [Online]

CODEN: LITIBR

Vol-1, Issue-1 ( $2^{\text {nd }}$ July, 2019)

Page No: $15-22$

DOI: 10.47365/litinfinite.1.1.2019.15-22

Section: Article

A presence that disturbs me with the joy

Of elevated thoughts; a sense sublime

Of something far more deeply interfused,

Whose dwelling is the light of setting suns,

And the round ocean and the living air,

And the blue sky, and in the mind of man;

A motion and a spirit, that impels

All thinking things, all objects of all thought,

And rolls through all things. ${ }^{3}$

Divine love when when interpreted by Tagore as an approach as "God is Love" is the first hope and He must be the last hope as well. Means that God is the ultimate hope and source of strength to human being. In his purview, and as adherent advocate of Buddha's philosophy, the belief of Nirvana,can be achieved through Love - the finial end and the ultimate goal according to Tagore. Sri Aurobindo holds the divine love as secret entry--to live in the awareness of eternity. It is the highest superconscient state of Sachchidananda.

Reason is torch bearer. It shows way but does not lead to what is called the destination. Reason is argumentative but love is self felicity. Reason proves to be the stimulus of sense desertion, love is self assimilation.Both Rumi and Iqbal propound the same pith and marrow:

Ashq Bir Murdaa Nabaashud Payidaar

Ashq Rebeir-jaan Afzaae Daar

Rumi

Hareemi Zath Hain Usk Neshama Abdee

Na Teri Khaq-e Uhod Hain Na Jalwa Gahe Sepath

........Iqbal

According to Rumi, has not there been the force of love, the world would have been frozen to death. It is stimulus and evolution its response. It is not a common life force, for God is love and love is to be beloved.Besides there is a likeness between the two asRumi says:

I want a heart which is split, part by part,

Because of the pain of seperation from God,

So that I might explain my longing and complaint

Iqbal adds:

When the lover fails to possess any love-fire,

He is like a bird without wings and desire ${ }^{4}$.

\footnotetext{
${ }^{3}$ Ibid

${ }^{4}$ Unknown author, the secret of meaning, Rumi's spiritual lessons on suffism, avaible at http:/www.thesecrtemeaning.com/book.pdf
} 
Litinfinite Journal

ISSN: 2582-0400 [Online]

CODEN: LITIBR

Vol-1, Issue-1 ( $2^{\text {nd }}$ July, 2019)

Page No: $15-22$

DOI: 10.47365/litinfinite.1.1.2019.15-22

Section: Article

Rumi discussed the relationship between lover and beloved 'Niyaz and Naz' in terms of Quranic Ayaa, (Fazkurunee Az Kurukum). For Rumi, it is out of love"that operates in the growth of plants, bursting of flowers, movement of fish in water, flight of birds in the air and man in creation of art, science and civilization" 5 .

For Iqbal, it is through love that made more lasting, more living, more burning and more growing. Everything fades away; nothing with stands. To cycles of time even the witticism transmits into apprehension and foolishness. The allusion of which are the Parahoon againest Moses. The following verses show the influence of Rumi on Iqbal:

"Love makes the dead bread wine of the soul, it makesthe mortal soul Immortal".

He further explains:

"Because of love bitternessbecomes sweet, because of love, copper becomes gold, because of love, turbid wine becomes clear. Becauseof love, troubles become the remedy, because of love, the dead come to life. Because of love, the king becomes a slave"7.

A few other verses of Rumi's Divan-i- Kabir on object of love:

"Every part, every element of the world is in love

Every part of it is intoxicated with the reunion

But these lovers will not tell you their secrets

Because a secret is revealed

only to one who is worthy

If the heavens had not been in love, its skies would nothave been so clear and pure.

If the sun had not been in love, there would have beenNo light, no brightness

on its face.

If the earth and the mountains had not been in love,

There would have beennot one grass growing on them.

If the see had not been aware of love, it would not have been fluttering so much,

it would have been frozen standing still in one place".

The Divine Love according to Ali Hujwiri that deals with the same subject matter as:

A quality which manifests itself, in the heart of the pious

Believer, in the form of vereration and magnification, so

That he seeks to satisify his beloved and becomes impatient

And restless in his desire for vision of Him, and cannot rest

With anyone except Him, and grows familiar with the recollection

Of Him, and abjures the recollection of everything besides.

\footnotetext{
${ }^{5}$ Dar Bashir Ahmad, Articles on Iqbal, Iqbal Academy Pakistan, P. No 120

${ }^{6}$ Rumi, Jalaluddin, Mathnavi, Vol...5, No 2014

7 Ibid, Vol 11, No 1529

${ }^{8}$ Diwan-i-kabir, Vol.VI, No 2674
} 
Litinfinite Journal

ISSN: 2582-0400 [Online]

CODEN: LITIBR

Vol-1, Issue-1 ( $\left.2^{\text {nd }} J u l y, 2019\right)$

Page No: $15-22$

DOI: 10.47365/litinfinite.1.1.2019.15-22

Section: Article

Repose becomes unlawful to him, and rest flees from him.

He is cut off from all habits and associations, and renounces

Sensual passion, and turns towards the court of love, and

Submits to the law of love, and knows God by His attributes

Of perfection. ${ }^{9}$

In the high way of Love, Rumi and Iqbal unanimously consider the self actualization linchpin. Love is complete in itself acutely. Love is God and God is love, what happens then to the love longing of the spirits plunged inmaterial complexion have preponderance over it is the rule that is there, that goes on. Metaphysically, love is a mysterious powerful weapon of man and also as an inherent force in the course of evolution of the world. Man is a puppet in the willy-nilly of matter. So to Iqbal and Rumi, it is only a love that liberates and emancipates man from suffering whereupon it takes flight.Bayazid Basthami in full agreement with Rumi and Iqbal holdsthat:

Love, is in its essence a divine gift, not anything that can be acquired If the whole world wished to attract love, they could not; and if they Made the utmost efforts to repel it, they could not, Those who love God Are those whom God loves. 'I fancied that I love Him, says a sufi, but on consideration $i$ saw that His love proceded mine. Love signifies the Passing away of the individual self; it is uncontrollable rapture, a God Send grace which must be sought by ardent prayer and aspiration. ${ }^{10}$

Man is man sometimes worse than beasts and sometimes superior to devil or approximately the same, If poisoned ever and ever. While explaing it further, both of them believe that knowledge is power but powerful is love. Reason is a cognitive baffling riddle ever confusing and misleading but love is pure destination. Love is much broader, longer, higher, taller and spacious than intellect...it is not subordinate to brain; it is subordinate to Heart or soul. limitleesness. They are on the same point in believing that it is the essence of life and universe. Love is mandatory to get out of its impudence. Mulana Rumi in His Mathnawi has thus used a unique term that is (NYE) flute. There is to Rumi a secret in the melody of the flute the secret of love.

\footnotetext{
${ }^{9}$ Unknown author, the secret of meaning, Rumi's spiritual lessons on suffism, avaible at http:/www.thesecrtemeaning.com/book.pdf, P. No 45

10 lbid
} 
Litinfinite Journal

ISSN: 2582-0400 [Online]

CODEN: LITIBR

Vol-1, Issue-1 ( $2^{\text {nd }}$ July, 2019)

Page No: $15-22$

DOI: 10.47365/litinfinite.1.1.2019.15-22

Section: Article

\section{Works cited}

i. Abdul, Hakim, Khalifa. The Metaphysics of Rumi, Lahore: The Institute of Islamic Culture, 1959.

ii. $\quad$ Afzal. Iqbal. Life and Works of Muhammad Jalal-ud-din Rumi, New Delhi: Kitabbhavan, 2003

iii. Aleem, H.A. Social Philosophy of Sir Muhammad Iqbal, A Critical Study, New Delhi: Adam Publishers and Distributers, 2008.

iv. Dalal. A.S. Sri Aurobindo and The Future Psychology, Pondicherry: Sri Aurobindo Ashram, 2014.

v. $\quad$ Iqbal. K. Urdu Collection. New Delhi: Farid Book Depot (Pvt) Ltd, 2006.

vi. $\quad$ Michael, R. The Life and Teachings of Jalal-ud-din Rumi, <2000/www.Santmatthetruth.de> Accessed on 12-02.2019 (Web)

vii. Mohammad. Iqbal. The Reconstruction of Religious Thought in Islam, Sheikh Mohammad Ashraf, Lahore: Javid Iqbal, 1962

viii. Nicholson, R, A. The Mystics of Islam. London: Routledge and Kegan Paul, 1975.

ix. Umar Muhammad Suheyl: (Editor) Iqbal Review, Journal of the Iqbal Academy, Pakistan, Oct..2007

x. $\quad$ Yousuf. C.S. Javeed Nama: (Persian Collection) of Iqbal, New Delhi: Ateqad Publishing House, 1993. 